\title{
Efficient Benzimidazolidinone Synthesis via Rhodium-Catalyzed Double-Decarbonylative C-C Activation/Cycloaddition between Isatins and Isocyanates
}

\author{
Rong Zeng, Peng-hao Chen, and Guangbin Dong ${ }^{*}$ \\ Department of Chemistry, University of Texas at Austin, Austin, Texas, 78712, USA
}

\begin{abstract}
The first decarbonylative cycloaddition of less-strained cyclic ketones (isatins) with isocyanates is reported. Initiated by $\mathrm{C}-\mathrm{C}$ activation, this distinct $[5-2+2]$ transformation provides a rapid entry to access various benzimidazolidinone derivatives, through which a wide range of isocyanates can be efficiently coupled with broad functional group tolerance. A modified one-pot process, combining Curtius rearrangement and $\mathrm{C}-\mathrm{C}$ activation, was also achieved by using acyl azides as the starting materials. Detailed mechanistic study revealed a surprising double-decarbonylative reaction pathway. The novel reactivity discovered in this basic research is expected to shed light on developing new heterocycle formation methods through a $\mathrm{C}-\mathrm{C} /$ isocyanate coupling.
\end{abstract}

\section{Keywords}

$\mathrm{C}-\mathrm{C}$ activation; isocyanate; isatin; cycloaddition; rhodium

Transition metal-catalyzed $\mathrm{C}-\mathrm{H}$ and $\mathrm{C}-\mathrm{C}$ activations followed by insertion of a $2 \pi$ unsaturated units have emerged as attractive byproduct-free approaches for constructing complex structures from readily available feedstock. ${ }^{1-2}$ Due to the ubiquity and pivotal role of amide bonds in biologically important molecules, isocyanates have been frequently employed as reaction partners for amide synthesis; ${ }^{3}$ consequently, direct addition of a $\mathrm{C}-\mathrm{H}$ or $\mathrm{C}-\mathrm{C}$ bond across isocyanate $\mathrm{C}=\mathrm{N}$ bonds would offer unique atom-efficient methods to access various nitrogen-containing compounds. In particular, cleavage of a cyclic $\mathrm{C}-\mathrm{C}$ bond accompanied by annulation with an isocyanate should offer an unusual approach to synthesize lactams (Scheme 1a). While a number of elegant approaches have been reported for coupling of isocyanates with unactivated $\mathrm{C}-\mathrm{H}$ bonds, ${ }^{4}$ the corresponding couplings involving $\mathrm{C}-\mathrm{C}$ activation are less common.

In 1987, Tsuji and co-workers developed the first palladium-catalyzed cycloaddition between vinyl cyclopropanes and isocyanates, ${ }^{5 a}$ in which the highly reactive donor-acceptor

\footnotetext{
*Corresponding Author gbdong@cm.utexas.edu.

Supporting Information is available free of charge via the Internet at http://pubs.acs.org. Detailed experimental procedures, characterization of products, and the X-ray analysis.

Notes

The authors declare no competing financial interest.
} 
cyclopropanes are needed (Scheme 1b). Later reports disclosed that Lewis acids could also promote this transformation benefiting from significant release of ring strain. ${ }^{5 b-5 c} \operatorname{In} 2013$, a novel rhodium(I)-catalyzed $\mathrm{C}-\mathrm{C}$ cleavage of cyclobutanols via $\beta$-carbon elimination followed by 1,2-addition with isocyanates was reported by Murakami for preparing linear amides (Scheme 1c). ${ }^{6}$ While strain release offers an important advantage for $\mathrm{C}-\mathrm{C}$ activation, ${ }^{2}$ to the best of our knowledge, cycloaddition of isocyanates via activation of less strained $\mathrm{C}-\mathrm{C}$ bonds has not been reported previously. Herein, we describe a decarbonylative regioselective cycloaddition between isatins and isocyanates, which involves a directed $\mathrm{C}-\mathrm{C}$ activation of isatins with extrusion of two CO molecules (Scheme 1d) ${ }^{7-8}$ This formal $[5-2+2]$ transformation provides a distinct strategy to convert readily available isatins into various benzimidazolidinone derivatives, a structural motif that has been widely found in pharmaceutical compounds.

Pioneered by Suggs, ${ }^{9}$ Jun, $,{ }^{2 g-2 i},{ }^{10}$, Murai, ${ }^{11}$ Douglas,,${ }^{8 d-8 g}$ Shi, ${ }^{12}$ and Wang,,${ }^{13 a}$ the use of directing groups (DGs) ${ }^{13 \mathrm{~b}-13 \mathrm{f}}$ has been demonstrated as a successful strategy to assist C-C activation of unstrained ketones. Our laboratory has been interested in developing catalytic methods through activation of less-strained cyclic ketones. For example, we recently reported a formal [5+2-1] transformation involving a directed activation of isatins and coupling with alkynes, ${ }^{14}$ in which the $\mathrm{C} 3-\mathrm{C} 4$ bond of isatins (e.g. 1a) was found to be efficiently cleaved by a low valent rhodium complex even at room temperature. Hence, this system provides an excellent platform to study the insertion of isocyanates. Isatin 1a and isocyanate 2a were employed as the initial substrates. A variety of metal-ligand combinations were screened. To our surprise, the expected mono-decarbonylative coupling product (4aa) was not observed; instead, benzimidazolidinone 3aa was isolated as the dominating product under various rhodium-catalyzed conditions (Table 1). This result indicated that double decarbonylation (two CO extrusions) occurred when an isocyanate was used as the coupling partner, and the corresponding $2 \pi$-insertion was completely regioselective. It was also interesting that no $\mathrm{C}-\mathrm{H}$ activation coupling product ${ }^{4}$ was observed when 3-methylpyridyl group was used as the DG.

After the reaction was carefully assayed, the benzimidazolidinone (3aa) was almost exclusively formed in $98 \%$ yield when $5 \mathrm{~mol} \%[\mathrm{Rh}(\operatorname{cod}) \mathrm{Cl}]_{2}$ and $20 \mathrm{~mol} \% \mathrm{AsPh}_{3}$ were discovered as the optimal combination (Table 1, entry 1). Control experiments were subsequently conducted to understand the role of each reactant. In the absence of the rhodium catalyst, no desired product was observed (entry 2). The conversion decreased dramatically without the $\mathrm{AsPh}_{3}$ ligand, and only $34 \%$ of 3aa was obtained (entry 3). Use of Wilkinson's catalyst $\left[\mathrm{Rh}\left(\mathrm{PPh}_{3}\right)_{3} \mathrm{Cl}\right]$ instead gave only $14 \%$ of the desired product together with a high recovery of the starting material (entry 4). Employment of other metal, such as $\mathrm{Ru}_{3}(\mathrm{CO})_{12}$, didn't afford any desired product (entry 5). Bi- or monodentate phosphine ligands, like Xantphos, dppp, dppb, $\mathrm{PCy}$, and $\mathrm{P}\left(\mathrm{C}_{6} \mathrm{H}_{2}-3,5-\left(\mathrm{CF}_{3}\right)_{2}\right)_{3}$, which have been proven to be efficient ligands for our previous $\mathrm{C}-\mathrm{C}$ activation reactions, however, all inhibited this reaction to various extents except $\mathrm{P}\left(\mathrm{C}_{6} \mathrm{H}_{4}-4-\mathrm{F}\right)_{3}$, regardless of their electronic properties (entries 7-12). In addition, sterically hindered Xphos and NHC ligand (IMes) decreased the yield to $7 \%$ and 29\%, respectively (entries 13-14). All these observations suggested that the $\mathrm{AsPh}_{3}$ ligand played a critical role for the high efficiency of this reaction. 
Besides 1,4-dioxane, $\mathrm{PhCl}$ also serves a competent solvent (entry 15). Furthermore, decreasing the temperature resulted in lower conversion (entry 16).

With the optimized conditions in hand, the reaction scope was first tested using substrate 1a with different isocyanates 2 (Table 2). Both aryl and alkyl substituted isocyanates with various electronic properties worked very well affording good to excellent yields of the corresponding benzimidazolidinone derivatives. A broad range of functional groups can be tolerated. Organic halides, such as aryl fluoride (2a), bromide (2c) and trifluoromethyl groups (2f) were compatible; aryl and alkyl substituted esters (2d and $\mathbf{2 l}$ ) remained untouched due to the near $\mathrm{pH}$ and redox neutral conditions. Sterically hindered isocyanates, such as 2,5-dimethoxyl-isocyanate (2g) and 1-naphthyl-isocyanate (2h), also provided high yields of products. When allylicisocyanate (2i) was used, the reaction underwent chemoselective $\mathrm{C}=\mathrm{N}$ insertion leaving the olefin moiety intact. Furthermore, regular alkyl (2j), benzyl (2k) and a-ester-isocyanate (2l) all gave high yields. X-ray crystal structures of products 3aa and 3al have also been obtained. ${ }^{15}$ Attempts to couple with other heterocumulenes, such as phenyl isothiocyanates or $N, N^{\prime}$-dicyclohexylcarbodiimide (DCC), remained unsuccessful.

The scope of the isatins and DGs was next investigated and compared (Table 3). Besides 3methyl-2-pyridyl-based DGs, other groups, such as 2-pyridyl (3bk and 3dk) and $1 \mathrm{H}$ indazol-1-yl (3ck), showed good reactivity for the transformation. Isatin substrates with a methyl group at the $C-5$ position led to the corresponding product $3 \mathbf{d k}$ in $84 \%$ yield. In addition, the $N$-benzyl protected isatin worked equally well (3ek). Finally, the 7-aza-isatin compound was also found to be a viable substrate, giving an interesting 1,3-dihydro- $2 \mathrm{H}$ imidazo[4,5- $b]$ pyridin-2-one (3fk) as the product.

Acyl azides are well-known precursors for preparing isocyanates through Curtius rearrangement. ${ }^{3,16}$ Thus, a one-pot process, which combines Curtius rearrangement and $\mathrm{C}-\mathrm{C}$ activation, was further developed to access benzimidazolidinone derivatives with a more complex substituent. Acyl azides were first transformed to the isocyanates after heating at $110{ }^{\circ} \mathrm{C}$ in $\mathrm{PhCl}$ for 2-3 hours, which were then treated with isatin 1a under the doubledecarbonylation conditions (Scheme 2). With this one-pot protocol, the ferrocene derivative (3am), acetophenone derivative (3an), and Vitamin E derivative (3ao) were efficiently synthesized from the corresponding acyl azides. It is not surprising that 4-formyl-benzoyl azide was not a suitable substrate due to the high reactivity of the aryl aldehyde moiety under the Rh catalysis conditions.

To have a better understanding of this transformation, the reaction mechanism was first explored with stoichiometric rhodium. According to our previously reported procedure, treatment of isatin 1a with $\left[\mathrm{Rh}\left(\mathrm{C}_{2} \mathrm{H}_{4}\right)_{2} \mathrm{Cl}\right]_{2}$ led to the cleavage of $\mathrm{C} 3-\mathrm{C} 4$ bond and formation of rhodacycle Int $\mathbf{1},{ }^{14}$ which was subsequently examined in the reaction with isocyanate $\mathbf{2 k}$. Unsurprisingly, the reaction proceeded smoothly and afforded the desired product 3ak in $81 \%$ yield (Eq. 1). This study indicates that the transformation is likely initiated by directed $\mathrm{C}-\mathrm{C}$ activation of isatins. 


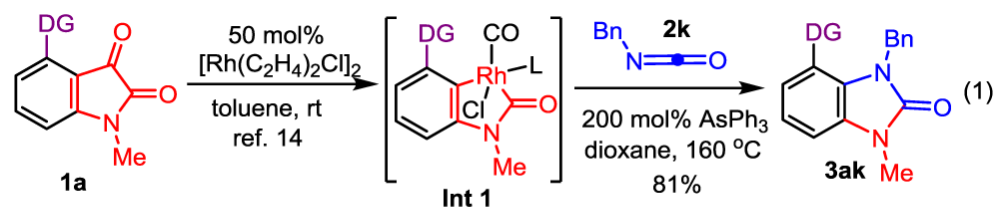

$\mathrm{DG}=3$-methyl-2-pyridinyl

Consequently, four possible reaction pathways are proposed as depicted in Scheme 3: (i) the isocyanate inserts into the aryl-Rh bond of Int $\mathbf{1}$ to give Int 2, which then undergoes a second decarbonylation to give the benzimidazolidinone product (path A); (ii) the isocyanate inserts into the acyl-Rh bond of Int $\mathbf{1}$ to generate Int 3, which is followed by a second decarbonylation and reductive elimination (path B); (iii) direct reductive elimination of Int $\mathbf{3}$, followed by a separate decarbonylative $\mathrm{C}-\mathrm{C}$ activation sequence, would also give product 3 (path C); (iv) through Int 1, double-decarbonylative $\mathrm{C}-\mathrm{C}$ activation of the isatin can occur to generate a four-membered rhodacycle Int $\mathbf{4}$, which then undergoes isocyanate insertion to afford product $\mathbf{3}$ (path $\mathbf{D}) .{ }^{17}$

To examine the feasibility of each reaction mechanism, first, 1,3dimethylquinazoline-2,4(1H,3H)-dione derivative $\mathbf{4}$ was prepared and subjected to the standard reaction conditions (Eq. 2). However, no desired benzimidazolidinone 3ap was observed even after 2 days, which excluded the 'second separate decarbonylative $\mathrm{C}-\mathrm{C}$ activation' mechanism (path $\mathbf{C}$ ). Second, when ${ }^{13} \mathrm{C}$-labeled isocyanate $\mathbf{2 b}-{ }^{\mathbf{1 3}} \mathbf{C}$, was subjected to the reaction with 2a under the standard conditions, the benzimidazolidinone 3ab- ${ }^{13} \mathbf{C}$ was isolated in $87 \%$ yield with more than $99 \%$ of ${ }^{13} \mathrm{C}$ incorporation at the carbonyl group (Eq. 3). This result strongly disfavoured both paths $\mathbf{A}$ and $\mathbf{B}$, in which partial or no ${ }^{13} \mathrm{C}$-labeled product should be observed (Scheme 3). Thus, path $\mathbf{D}$, involving double decarbonylation first and then isocyanate insertion, should be the most reasonable reaction pathway.
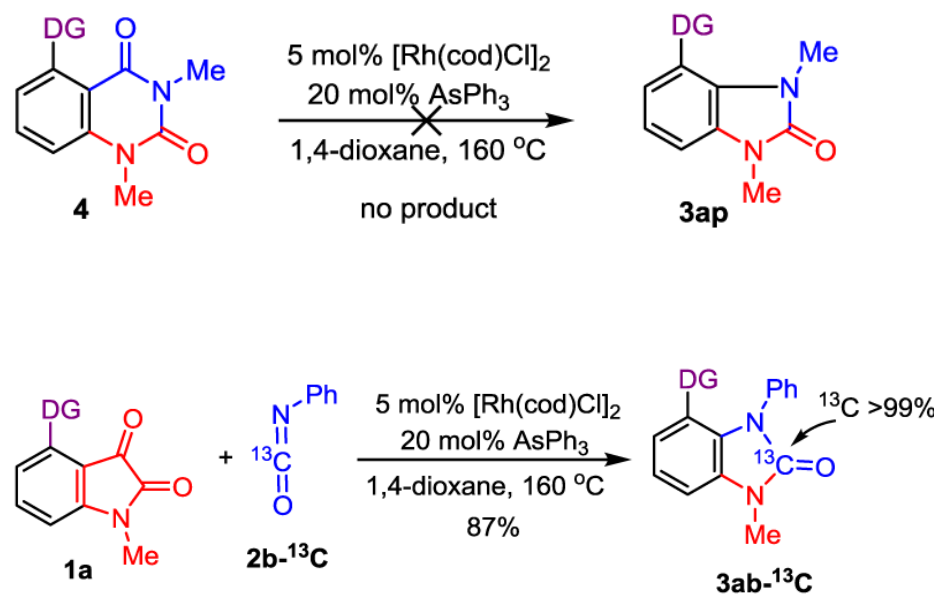
In summary, we have developed a unique Rh-catalyzed [5-2+2] transformation through directed $\mathrm{C}-\mathrm{C}$ activation of isatins followed by "double decarbonylative cycloaddition" with isocyanates. A broad range of isocyanates can be coupled with high efficiency, and the corresponding benzimidazolidinone derivatives can be obtained in good to excellent yields with high functional group tolerance. In addition, a modified one-pot process combining a Curtius rearrangement and $\mathrm{C}-\mathrm{C}$ activation was also realized. Furthermore, the mechanistic study disclosed a new mode of reactivity of isatins and strongly supported the proposed double decarbonylation pathway. The novel mode of reactivity discovered here is expected to shed light on developing new heterocycle formation methods through a $\mathrm{C}-\mathrm{C} /$ isocyanate coupling. Efforts on extending to other systems (e.g. use of a temporary DG) are ongoing.

\section{Supplementary Material}

Refer to Web version on PubMed Central for supplementary material.

\section{ACKNOWLEDGMENT}

We thank CPRIT for startup funds, NIGMS (R01GM109054) and the Welch Foundation (F 1781) for research grants. GD is a Searle Scholar. We thank Dr. Ying Xia for checking the reproducibility of the experiments. We thank Dr. M. C. Young for X-ray crystallographic analysis and proofreading of the manuscript. We are also grateful to Johnson Matthey for a donation of Rh salts.

\section{REFERENCES}

(1). (a) Kakiuchi F, Murai S. Acc. Chem. Res. 2002; 35:826-834. For selected reviews on C-H functionalization coupling with unsaturated units, see: [PubMed: 12379135] (b) Ritleng V, Sirlin C, Pfeffer M. Chem. Rev. 2002; 102:1731-1770. [PubMed: 11996548] (c) Kakiuchi F, Kochi T. Synthesis. 2008:3013-3039.(d) Foley NA, Lee JP, Ke Z, Gunnoe TB, Cundari TR. Acc. Chem. Res. 2009; 42:585-597. [PubMed: 19296659] (e) Kitamura T. Eur. J. Org. Chem. 2009:11111125.(f) Colby DA, Bergman RG, Ellman JA. Chem. Rev. 2010; 110:624-655. [PubMed: 19438203] (g) Yoshikai N. Synlett. 2011:1047-1051.(h) Colby DA, Tsai AS, Bergman RG, Ellman JA. Acc. Chem. Res. 2012; 45:814-825. [PubMed: 22148885]

(2). (a) Jones WD. Nature. 1993; 364:676-677. For selected reviews on transition-metal-mediated C-C bond activations, see: (b) Murakami M, Ito Y. Top. Organomet. Chem. 1999; 3:97-129.(c) Rybtchinski B, Milstein D. Angew. Chem. Int. Ed. 1999; 38:870-883.(d) Perthuisot C, Edelbach BL, Zubris DL, Simhai N, Iverson CN, Müller C, Satoh T, Jones WD. J. Mol. Catal. A. 2002; 189:157-168.(e) Van der Boom ME, Milstein D. Chem. Rev. 2003; 103:1759-1792. [PubMed: 12744693] (f) Satoh T, Miura M. Top. Organomet. Chem. 2005; 14:1-20.(g) Jun C-H. Chem. Soc. Rev. 2004; 33:610-618. [PubMed: 15592626] (h) Jun C-H, Park JW. Top. Organomet.Chem. 2007; 24:117-143.(i) Park YJ, Park J-W, Jun C-H. Acc. Chem. Res. 2008; 41:222-234. [PubMed: 18247521] (j) Necas D, Kotora M. Curr. Org. Chem. 2007; 11:15661591.(k) Crabtree RH. Chem. Rev. 1985; 85:245-269.(1) Kondo T, Mitsudo TA. Chem. Lett. 2005; 34:1462-1467.(m) Ruhland K. Eur. J. Org. Chem. 2012:2683-2706.(n) Korotvicka A, Necas D, Kotora M. Curr. Org. Chem. 2012; 16:1170-1214.(o) Seiser T, Saget T, Tran DN, Cramer N. Angew. Chem. Int. Ed. 2011; 50:7740-7752.(p) Murakami M, Matsuda T. Chem. Commun. 2011; 47:1100-1105.(q) Dermenci A, Coe PW, Dong G. Org. Chem. Front. 2014; 1:567-584.(r) Dong, G., editor. C-C bond activation in Topics in Current Chemistry. Vol. 346. Springer-Verlag; Berlin Heidelberg: 2014. (s) Dermenci A, Dong G. Sci. China, Chem. 2013:685-701.(t) Souillart L, Cramer N. Chem. Rev. 2015; 115:9410-9464. [PubMed: 26044343] (u) Chen F, Wang T, Jiao N. Chem. Rev. 2014; 114:8613-8661. [PubMed: 25062400]

(3). (a) Ulrich, H. Chemistry and Technology of Isocyanates. Son, Chichester; John Wiley: 1997. For books and reviews on isocyanates, see:(b) Braunstein P, Nobel D. Chem. Rev. 1989; 89:19271945.(c) Allen AD, Tidwell TT. Chem. Rev. 2013; 113:7287-7342. [PubMed: 23767795] 
(4). (a) Kuninobu Y, Tokunaga Y, Kawata A, Takai K. J. Am. Chem. Soc. 2006; 128:202-209. For selected reports on C-H coupling with isocyanates, see: [PubMed: 16390148] (b) Kuninobu Y, Kikuchi K, Tokunaga Y, Nishina Y, Takai K. Tetrahedron. 2008; 64:5974-5981.(c) Hesp KD, Bergman RG, Ellman JA. J. Am. Chem. Soc. 2011; 133:11430-11433. [PubMed: 21714533] (d) Muralirajan K, Parthasarathy K, Cheng C-H. Org. Lett. 2012; 14:4262-4265. [PubMed: 22873354] (e) Hou W, Zhou B, Yang Y, Feng H, Li Y. Org. Lett. 2013; 15:1814-1817. [PubMed: 23560588] (f) De Sarkar S, Ackermann L. Chem. Eur. J. 2014; 20:13932-13936. [PubMed: 25201510] (g) Shi X-Y, Renzetti A, Kundu S, Li C-J. Adv. Synth. Catal. 2014; 356:723-728.(h) Hummel JR, Ellman JA. Org. Lett. 2015; 17:2400-2403. [PubMed: 25945401] (i) Li J, Ackermann L. Angew. Chem. Int. Ed. 2015; 54:8551-8554.(j) Han S, Mishra NK, Sharma S, Park J, Choi M, Lee S-Y, Oh JS, Jung YH, Kim IS. J. Org. Chem. 2015; 80:8026-8035. [PubMed: 26194785] (k) Geng X, Wang C. Org. Biomol. Chem. 2015; 13:7619-7623. [PubMed: 26100519]

(5). (a) Yamamoto K, Ishida T, Tsuji J. Chem. Lett. 1987:1157-1158.(b) Goldberg AFG, O'Connor NR, Craig II RA, Stoltz BM. Org. Lett. 2012; 14:5314-5317. [PubMed: 23046060] (c) Tsunoi S, Maruoka Y, Suzuki I, Shibata I. Org. Lett. 2015; 17:4010-4013. [PubMed: 26247349]

(6). Ishida N, Nakanishi Y, Murakami M. Angew. Chem. Int. Ed. 2013; 52:11875-11878.

(7). (a) Kondo T, Nakamura A, Okada T, Suzuki N, Wada K, Mitsudo TA. J. Am. Chem. Soc. 2000; 122:6319-6320. For a recent review on decarbonylative cross couplings, see: ref 2 s. For representative works of catalytic $\mathrm{C}-\mathrm{C}$ activation with subsequent insertion of olefins or alkynes with decarbonylation, see: (b) Kondo T, Taguchi Y, Kaneko Y, Niimi M, Mitsudo T-A. Angew. Chem. Int. Ed. 2004; 43:5369-5372.(c) Yamamoto Y, Kuwabara S, Hayashi H, Nishiyama H. Adv. Synth. Catal. 2006; 348:2493-2500.(d) Chen P-H, Xu T, Dong G. Angew. Chem., Int. Ed. 2014; 53:1674-1678.

(8). (a) Edelbach BL, Lachicotte RJ, Jones WD. Organometallics. 1999; 18:4040-4049. For representative works of catalytic $\mathrm{C}-\mathrm{C}$ activation with subsequent insertion of olefins or alkynes without decarbonylation, see: (b) Murakami M, Itahashi T, Ito Y. J. Am. Chem. Soc. 2002; 124:13976-13977. [PubMed: 12440879] (c) Ko HM, Dong G. Nat. Chem. 2014; 6:739-744. [PubMed: 25054946] (d) Wentzel MT, Reddy VJ, Hyster TK, Douglas CJ. Angew. Chem. Int. Ed. 2009; 48:6121-6123.(e) Dreis AM, Douglas CJ. J. Am. Chem. Soc. 2009; 131:412-413. [PubMed: 19105696] (f) Lutz JP, Rathbun CM, Stevenson SM, Powell BM, Boman TS, Baxter CE, Zona JM, Johnson JB. J. Am. Chem. Soc. 2012; 134:715-722. [PubMed: 22133417] (g) Rathbun CM, Johnson JB. J. Am. Chem. Soc. 2011; 133:2031-2033. [PubMed: 21271701] (h) Narasaka K, Koga Y. Chem. Lett. 1999; 28:705-706.(i) Li C, Zhang H, Feng J, Zhang Y, Wang J. Org. Lett. 2010; 12:3082-3085. [PubMed: 20536190] (j) Jiao L, Lin M, Zhuo L-G, Yu Z-X. Org. Lett. 2010; 12:2528-2531. [PubMed: 20465285] (k) Wender PA, Takahashi H, Witulski B. J. Am. Chem. Soc. 1995; 117:4720-4721.(1) Shaw MH, Melikhova EY, Kloer DP, Whittingham WG, Bower JF. J. Am. Chem. Soc. 2013; 135:4992-4995. [PubMed: 23488745] (m) Weintz H-J, Binger P. Tetrahedron Lett. 1985; 26:4075-4078.(n) Nakao Y, Oda S, Hiyama T. J. Am. Chem. Soc. 2004; 126:13904-13905. For C-CN bond cleavage: [PubMed: 15506734] (o) Xu T, Dong G. Angew. Chem., Int. Ed. 2012; 51:7567-7571.

(9). (a) Suggs JW, Cox SD. J. Organomet. Chem. 1981; 221:199-201.(b) Suggs JW, Jun C-H. J. Am. Chem. Soc. 1984; 106:3054-3056.(c) Suggs JW, Jun C-H. J. Am. Chem. Soc. 1986; 108:4679_ 4681.(d) Suggs JW, Jun C-H. J. Chem. Soc., Chem. Commun. 1985:92-93.

(10). (a) Lee H, Jun C-H. J. Am. Chem. Soc. 1999; 121:880-881.(b) Jun C-H, Lee H, Lim S-G. J. Am. Chem. Soc. 2001; 123:751-752. [PubMed: 11456596]

(11). Chatani N, Ie Y, Kakiuchi F, Murai S. J. Am. Chem. Soc. 1999; 121:8645-8646.

(12). (a) Lei Z-Q, Pan F, Li H, Li Y, Zhang X-S, Chen K, Wang X, Li Y-X, Sun J, Shi Z-J. J. Am. Chem. Soc. 2015; 137:5012-5020. [PubMed: 25843169] (b) Li H, Li Y, Zhang X-S, Chen K, Wang X, Shi Z-J. J. Am. Chem. Soc. 2011; 133:15244-15247. [PubMed: 21875139] (c) Chen K, Li H, Lei Z-Q, Li Y, Ye W-H, Zhang L-S, Sun J, Shi Z-J. Angew.Chem. Int. Ed. 2012; 51:98519855.(d) Lei Z-Q, Li H, Li Y, Zhang X-S, Chen K, Wang X, Sun J, Shi Z-J. Angew. Chem. Int. Ed. 2012; 51:2690-2694.

(13). (a) Wang J, Chen W, Zuo S, Liu L, Zhang X, Wang J. Angew. Chem. Int. Ed. 2012; 51:1233412338.(b) Gozin M, Weisman A, Ben-David Y, Milstein D. Nature. 1993; 364:699-701. For other reports using a directing group for $\mathrm{C}-\mathrm{C}$ cleavage, see: (c) Liou S-Y, Gozin M, Milstein D. J. 
Am. Chem. Soc. 1995; 117:9774-9775.(d) Rybtchinski B, Vigalok A, Ben-David Y, Milstein D. J. Am. Chem. Soc. 1996; 118:12406-12415.(e) Ozkal E, Cacherat B, Morandi B. ACS Catal. 2015; 5:6458-6462.(f) Tashiro S, Yamada M, Shionoya M. Angew. Chem. Int. Ed. 2015; 54:5351-5354.

(14). Zeng R, Dong G. J. Am. Chem. Soc. 2015; 137:1408-1411. [PubMed: 25569352]

(15). CCDC numbers of 3aa and 3al are 1430588 and 1430589, respectively. For more information on the crystal structures, please see SI

(16). (a) Smith PA. Org. React. 1946:337-449. For reviews on Curtius rearrangement, see: (b) Banthorpe, DV.; Patai, S., editors. Rearrangements Involving Azido Groups in The Chemistry of the Azide Group. Wiley; New York: 1971. p. 397-440.

(17). (a) Hanley PS, Hartwig JF. Angew, Chem. Int. Ed. 2013; 52:8510-8525. For a review on migratory insertion of unsaturated units into metal-oxygen and metal nitrogen bonds, see: (b) Whited MT, Qiu L, Kosanovich AJ, Janzen DE. Inorg. Chem. 2015; 54:3670-3679. For example on migratory insertion of isocyanate into $\mathrm{Rh}-\mathrm{N}$ bond, see: [PubMed: 25799316] 


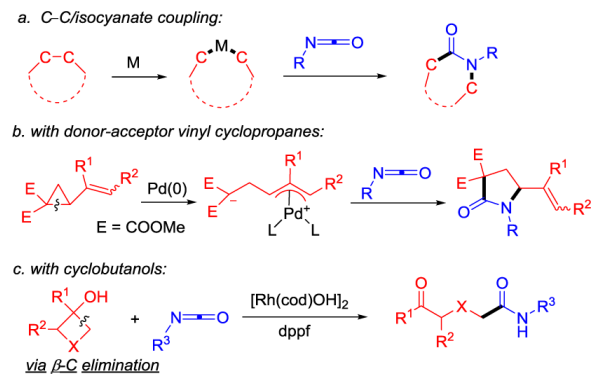

d. This work: with isatins

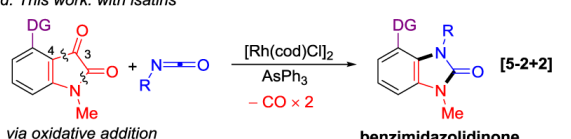

via oxidative addition benzimidazolidinone

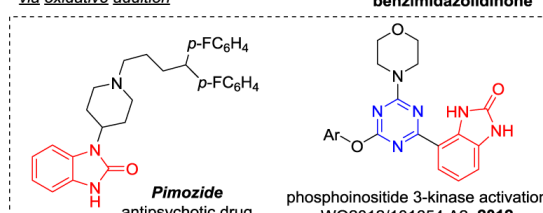

phosp

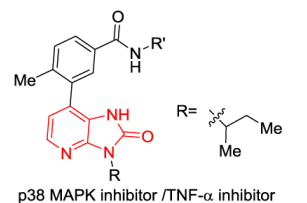

P38 MAPK inhibitor $/$ NF- $\alpha$ inhibitor
WO2011/21678 A1, 2011

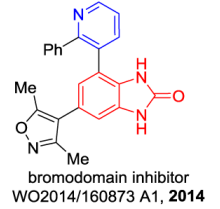

Scheme 1.

Transition metal-catalyzed $\mathrm{C}-\mathrm{C}$ cleavage and its coupling with isocyanates 

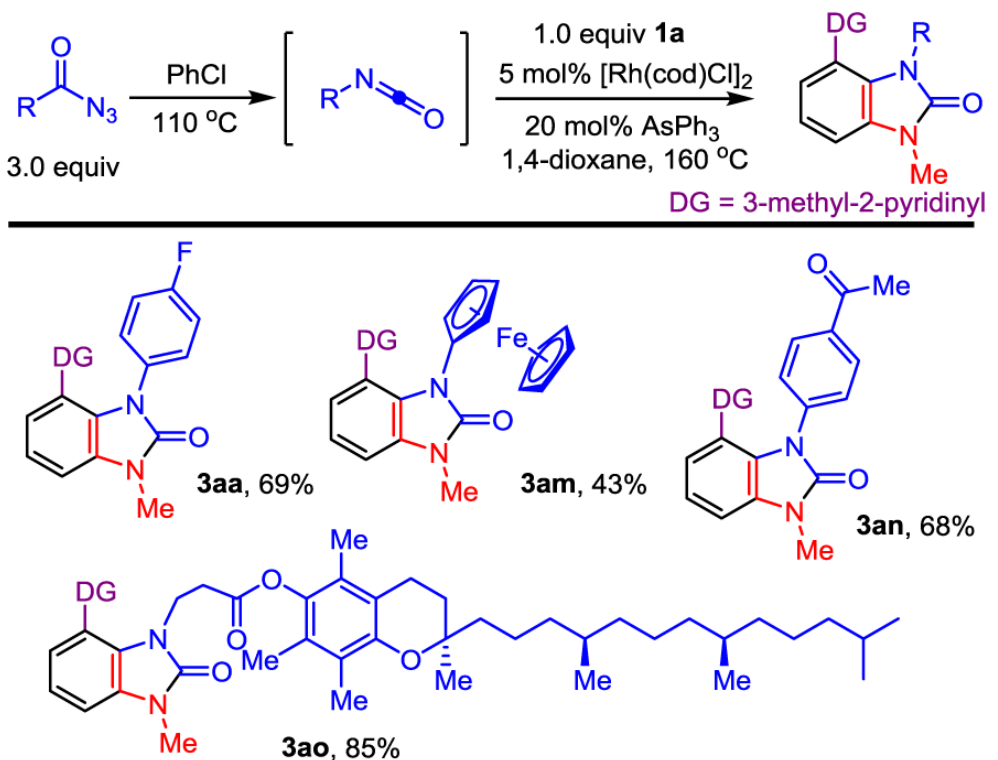

Scheme 2.

Curtius Rearrangement/C $-\mathrm{C}$ activation/isocyanate insertion 


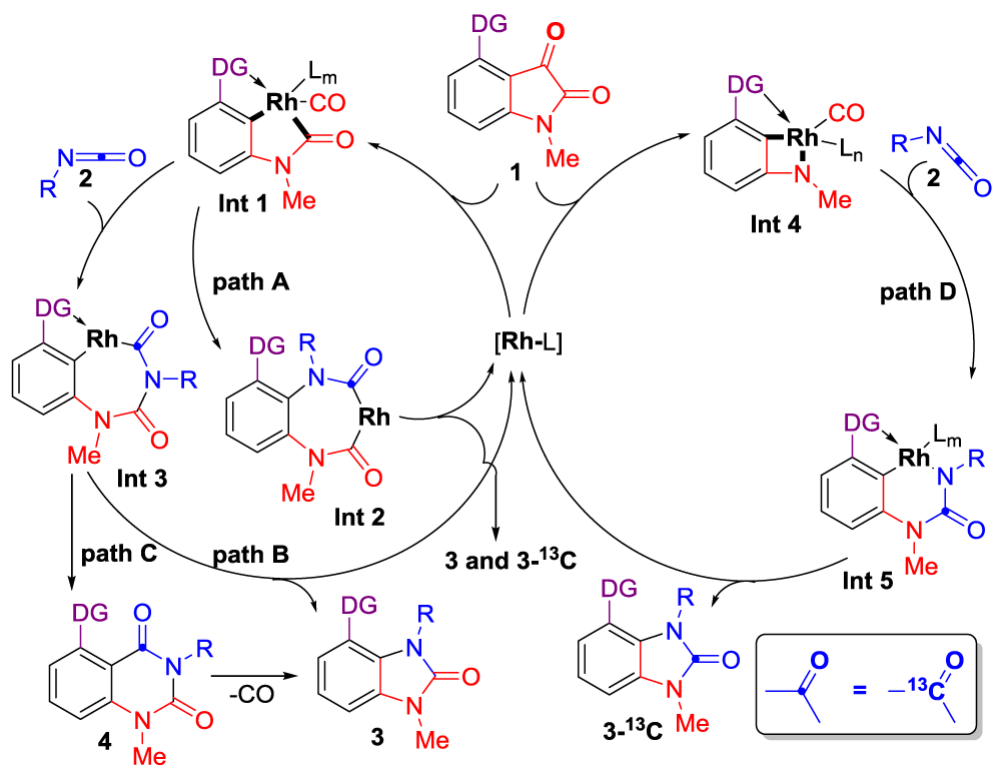

Scheme 3.

Possible reaction pathways 


\section{Table 1}

Control experiments.

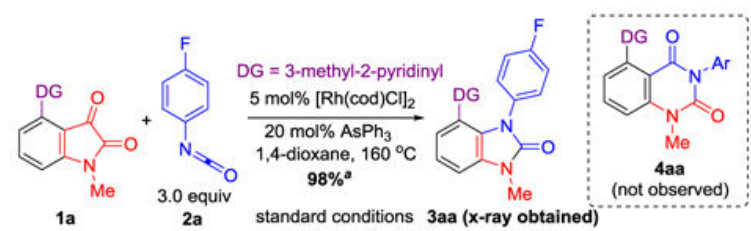

\begin{tabular}{|c|c|c|c|}
\hline entry & change from standard conditions & conversion / \% & $3 \mathrm{aa} / \%^{a}$ \\
\hline 1 & None & 99 & 98 \\
\hline 2 & Without Rh catalyst & $\mathbf{0}$ & $\mathbf{0}$ \\
\hline 3 & Without $\mathrm{AsPh}_{3}$ & 34 & 34 \\
\hline 4 & $\mathrm{RhCI}\left(\mathrm{PPh}_{3}\right)_{3}$ instead of $[\mathrm{Rh}(\operatorname{cod}) \mathrm{CI}]_{2}$ & 15 & 14 \\
\hline 5 & $\mathrm{Ru}_{3}(\mathrm{CO})_{12}$ instead of $[\mathrm{Rh}(\operatorname{cod}) \mathrm{CI}]_{2}$ & 19 & $\mathbf{0}$ \\
\hline 6 & Xantphos instead of $\mathrm{AsPh}_{3}$ & 7 & $\mathbf{0}$ \\
\hline 7 & dppb instead of $\mathrm{AsPh}_{3}$ & 30 & 8 \\
\hline 8 & dppp instead of $\mathrm{AsPh}_{3}$ & 16 & 9 \\
\hline 9 & $\mathrm{PCy}_{3}$ instead of $\mathrm{AsPh}_{3}$ & 28 & 16 \\
\hline 10 & $\mathrm{P}\left(\mathrm{C}_{6} \mathrm{H}_{4}-4-\mathrm{OMe}\right)_{3}$ instead of $\mathrm{AsPh}_{3}$ & 28 & 13 \\
\hline 11 & $\mathrm{P}\left(\mathrm{C}_{6} \mathrm{H}_{4}-4-\mathrm{F}\right)_{3}$ instead of $\mathrm{AsPh}_{3}$ & 91 & 78 \\
\hline 12 & $\mathrm{P}\left(\mathrm{C}_{6} \mathrm{H}_{2}-3,5-\left(\mathrm{CF}_{3}\right) 2\right)_{3}$ instead of $\mathrm{AsPh}_{3}$ & 10 & 10 \\
\hline 13 & Xphos instead of $\mathrm{AsPh}_{3}$ & 22 & 7 \\
\hline 14 & IMes instead of $\mathrm{AsPh}_{3}$ & 41 & 29 \\
\hline 15 & PhCI instead of 1,4-Dioxane & 96 & 72 \\
\hline 16 & Temperature was $150{ }^{\circ} \mathrm{C}$ & 31 & 29 \\
\hline
\end{tabular}

${ }^{a}$ Determined by crude ${ }^{1} \mathrm{H}$ NMR using 1,1,2,2-tetrachloroethane as the internal standard. 


\section{Table 2}

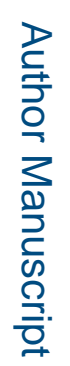

The reaction scope of isocyanates ${ }^{a}$

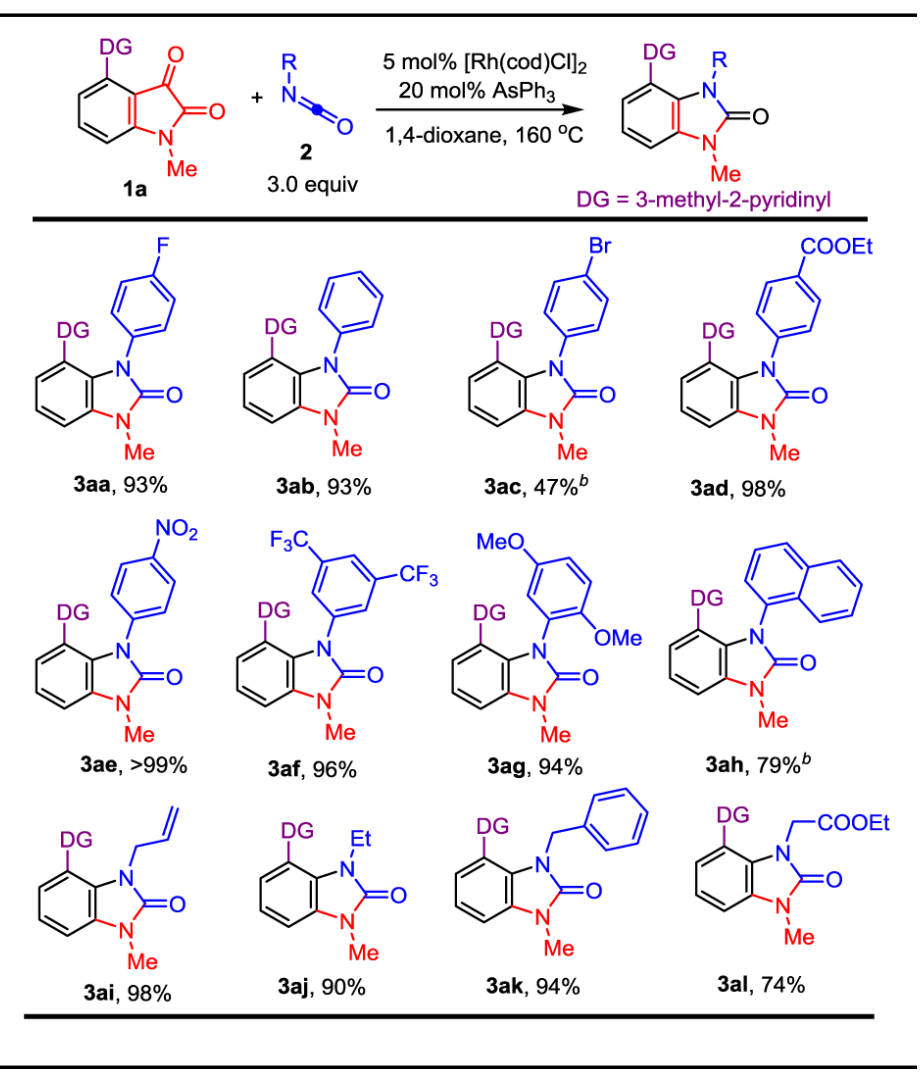

${ }^{a}$ All the yields are isolated yields.

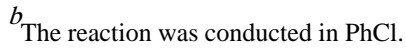




\section{Table 3}

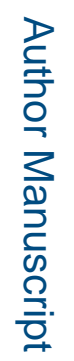

The reaction scope of isatins

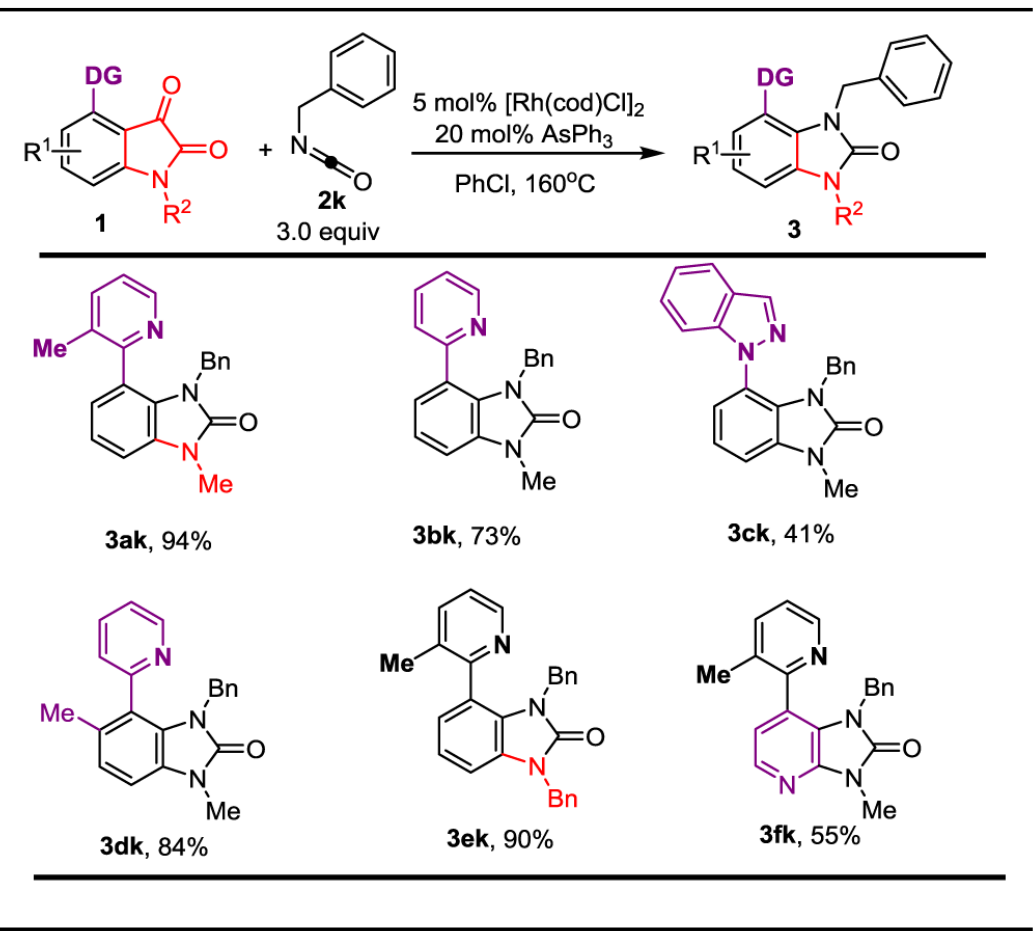

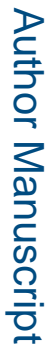

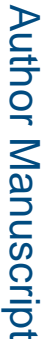

3ek, $90 \%$ 